Article

\title{
Mystical Body Theodicy
}

\author{
Joshua C. Thurow \\ Department of Philosophy and Classics, The University of Texas at San Antonio, One UTSA Circle, San Antonio, \\ TX 78249, USA; joshua.thurow@utsa.edu
}

Received: 1 December 2017; Accepted: 25 January 2018; Published: 31 January 2018

\begin{abstract}
In this paper I develop a new theodicy-Mystical Body Theodicy. This theodicy draws on the Christian doctrine of the mystical body of Christ to argue that some evil can be defeated by a set of three goods connected with increasing the unity of humanity through love. This theodicy also helps three other prominent theodicies avoid objections.
\end{abstract}

Keywords: problem of evil; theodicy; Marilyn Adams; Richard Swinburne; mystical body

\section{Introduction}

At the highest level of abstraction, the problem of evil goes like this:

(PE1) There are evils of type F.

(PE2) If God existed God would not allow evils of type F. Therefore,

(PE3) God does not exist. ${ }^{1}$

There are many instances of this argument pattern. Each new substitution for ' $\mathrm{F}$ '—e.g., gratuitous evils, horrendous evils, natural evils, sufferings of non-human animals before there were humans, etc.- - gets you a new argument, and there are a legion of such arguments.

What's a theist to do with (from his perspective) all these weeds? He'll first have to decide whether to take a targeted or global approach to eliminating the weeds. Can each argument be handled one at a time (or a few at a time), each requiring unique and carefully formulated treatments? This is the targeted approach. Or, can the whole lot of them be eliminated with one special treatment - the philosophical equivalent of Roundup to keep your theistic lawn clean? This is the global approach. He'll then have to decide whether to attack the weeds directly, i.e., argue that at least one of their premises are false, or to defend against the weeds by taking away what they need to grow, i.e., by arguing that there isn't good reason to believe their premises.

Skeptical theism is currently the most discussed and most popular response to the problem of evil. ${ }^{2}$ It goes for the most economical response to the problem: a global defense. As such, it argues that one special treatment - a certain degree of skepticism about what is good and right and about what reasons God might have for acting - undermines reason to believe at least one premise of every instance of the above argument (usually PE2, but sometimes PE1 depending on how the evil is described). No need to look at each instance one-by-one. And no need to try to argue against a premise in each; arguing that $\mathrm{p}$ is false is often harder than arguing there aren't good reasons to believe $\mathrm{p}$.

In this paper I want to explore perhaps the most prominent general alternative response: theodicy. A theodicy, as I shall understand the term, is an account of why, if God exists, God might allow evil. Theodicies can be targeted or global — that is, they can give accounts of why God allows a certain set of

\footnotetext{
This is a deductive formulation, but obviously it also could be formulated probabilistically.

2 See (Bergmann 2009; Dougherty and McBrayer 2014; Howard-Snyder 1996; McBrayer and Howard-Snyder 2013) for introductory and state-of-the-art essays on skeptical theism.
} 
evils, or all evils. ${ }^{3}$ Theodicies can also be weak or strong — that is, they can assert merely that, if God exists, God might have these reasons for allowing evil or they can assert more strongly that, if God exists, God probably has these reasons for allowing evil. Theodicies can thus respond to the problem of evil in either a targeted or global manner, and through either an attack or a defense. Thus some theodicies can, like skeptical theism, offer up a global defense. What distinguishes theodicies from skeptical theism is the manner of response: theodicies propose that God might allow evils for such-and-such reasons, whereas skeptical theists (qua being skeptical theists) make no such proposal.

What can the theodicist reasonably draw on in construction of such proposals? Marilyn McCord Adams's answer to this question vastly expanded the territory for theodicy, enabling her to develop her own detailed, theologically sophisticated, and justly-celebrated theodicy. She argues that much work on the problem of evil assumes the Myth of Shared Values-that value theory is religiously-neutral, thus common ground for both an atheist and a theist. This myth would, if taken seriously, imply that a theodicy must appeal to goods that are shared between theist and atheist. Adams persuasively argues that this myth is false; not only is there considerable disagreement in normative ethical theory among atheists, but theists believe in goods that the atheist rejects-most notably God, a being of supreme goodness (Adams 1999a, pp. 11-12). Those additional goods endorsed by theists may alter their overall value theory, thus giving them additional resources for explaining why God allows evil. Furthermore, it is appropriate for theists to use those additional goods in their theodicies because it is their beliefs that are being attacked by the problem of evil. If you want to argue that somebody's god doesn't exist, you need to target their god-including all of that God's important characteristics, concerns, and actions-not some abstraction of their god. If you just target some abstraction of their god, they can easily respond, "sure, that god (or a god that had merely those abstract features) may not exist. But that's not the god I believe in. I believe in this one. Tell me why this one doesn't exist." So theodicists can reasonably appeal to both shared values (such as there are) and values that are distinct to their theistic belief system.

Although Adams's insight here has led to the production of richer theodicies-her own is a fine example-I think that there are still gains to be made. Like Adams, I will work from within the Christian tradition to develop a theodicy for the Christian God. In this paper I present what I call Mystical Body Theodicy. It draws on the Christian doctrine of the mystical body of Christ according to which all those who follow Jesus become part of his mystical body with him as the head of the body. The whole body is a union, bound together in love through the action of the Holy Spirit. This theodicy helps explain in a distinctive way why God might allow some evils and it also helps to repair some problems with other theodicies. I argue that mystical body theodicy, combined with other popular theodicies, offers a very broad theodicy (not narrowly targeted), but not quite a global one. It is at least a weak theodicy and thus a defense, but I shall also argue that there are reasons to think it is a strong theodicy, and so may ground an attack. Furthermore there are some virtues to offering a strong theodicy that have been obscured in analytic philosophical discussion of the problem of evil. Indeed, they are somewhat obscured by Adams's rejection of the myth of shared values.

Here then is a roadmap of what is to come. In section two I criticize three prominent theodicies-those of Swinburne, Hick, and Adams. In section three I explain the doctrine of the mystical body of Christ. In section four I draw out some of the implication of this doctrine for theodicy, one such being that it can protect Swinburne, Hick, and Adams from the criticisms leveled against them in section two. In section five I discuss some limitations of mystical body theodicy, and in section six I conclude the argument and develop one final advantage of mystical body theodicy that comes from approaching it as a strong theodicy.

3 My notion of a global theodicy is thus different from Marilyn Adams's notion of a 'global approach' to the problem of evil (Adams 1999a, chp. 2). Her notion has to do with accounting for evil by looking at the global balance of good and evil. Mine has no such association. Her 'global approach' is one way to offer a global theodicy (in my sense), but it isn't the only way. 


\section{Some Contemporary Theodicies: Swinburne, Hick, Adams}

Richard Swinburne, John Hick, and Marilyn McCord Adams have carefully developed distinct theodicies. Each theodicy highlights a certain sort of good that, they propose, is present in the world or in humans, is connected in some sort of intimate way with various evils, and is such that a good God might well allow these evils given those goods exist that are intimately connected with these evils. Each theodicy has come under criticism. I shall present some of their main criticisms here. I do so not to show that mystical body theodicy is superior to these theodicies. Rather, I aim to show that mystical body theodicy can strengthen these theodicies. Theodicies are not usually in competition; they can be intertwined like strands in a durable cord.

\subsection{Swinburne, Free Will, and the Good of Being of Use}

Swinburne's theodicy of moral evil—evil that results from agency-builds on the classic free will defense. He takes it that libertarian free will to perform morally serious acts is a great good because such freedom is required to be able to have responsibility for oneself and others, which is itself a great good (Swinburne 1998, p. 88ff). But of course humans may freely choose to do bad or wrong things. God must allow humans to make such bad choices in order to allow them to have serious free will. Being the victim of a bad action is thereby bad, but also in a certain way good because "it is also a good thing to be of use, to help, to serve, either through freely exercising power in the right way, or through doing it naturally and spontaneously, or even by being used as the vehicle of a good purpose" (Swinburne 1998, p. 101). Victims are of use as an arena in which the perpetrator exercises significant free will, which is a great good. So, their being of use in this way is itself a great good.

Some will balk at this claim. Swinburne himself admits that "we do not, most of us, think that most of the time" (Swinburne 1998, p. 101). Plausibly, how good it is to be of use to end A depends upon the value of A itself. Although most people grant that free will is good, there is considerable disagreement about how good it is. And even if the having of free will is a great good, it doesn't follow that every exercise of free will is good. Plausibly, the good of exercising free will is at best minor when you use it to do something bad. If the good of being of use in doing A depends upon how good A is, then the good of being of use in exercising free will in such a case is minor. Surely it isn't large enough to outweigh the badness of the wrong action. So the good of being of use in others' exercise of free will isn't a significant enough good to play much of a role in a theodicy.

Later on I show how mystical body theodicy offers a more significant good that we-including victims of bad free choices-can be of use for.

\subsection{Hick, Soul-Making, and Dysteleological Evils}

John Hick's theodicy builds on the Irenaean idea that humans begin their existence as immature. God molds and shapes their souls by arranging the human environment so that they are pushed to become more virtuous. This molding and shaping can continue on into the afterlife. Evils induce some of that transformation. People become more courageous by facing real dangers (both natural and moral); they become more prudent by performing and witnessing others perform bad acts, seeing their consequences and thereafter deciding to turn away from them; they acquire temperance by wrestling with temptations, sometimes failing and learning ways to avoid future failure; they become loving by suffering through the pains of relationships and by having compassion on those who have suffered. Humans have to freely cooperate with and engage in this process; it wouldn't be good for God to force each transformation on them. ${ }^{4}$

Hick acknowledges that there are evils that appear not to contribute to soul making- "dysteleological evils," he calls them. But dystelological evils as a class, he argues,

4 See (Hick 1966) especially Sections III and IV for the full account of his soul making theodicy. 
are thereby mysterious and their mystery helps us to more fully sympathize with those who suffer them, as we are less likely to sympathize when we can see that suffering leads to the person's good. Dysteleological evils thus in fact contribute something to soul making!

Adams criticizes Hick on this point, arguing that this can't be a full explanation for why a good God would allow dysteleological evils (Adams 1999a, pp. 52-53). For God must also be good to those who have suffered evils, and the benefit Hick describes seems too generalized to count as being good to the victim; granted perhaps God is good to humanity in allowing them. Hick, she grants, might suggest that God gives those who have suffered dysteleological evils an opportunity in the afterlife to see how their suffering has led to the soul making of others; they embrace how they have been of use to others and thus become more virtuous and Godlike. In this way God is good to them. Adams thinks something is still missing. "Would not Divine Love focused on created persons lend positive meaning, not only to the individual's life as a whole, but also to any careers in which he or she participates in horrors?" (Adams 1999a, p. 53). Perhaps God has been good to the sufferer in her life as a whole, from the standpoint of the afterlife, but Adams thinks God should also be good to her in the phase of her life when she suffers. That she will learn a lesson later in the afterlife isn't apt for the suffering phase. Adams concludes, "to give this life, or any career involving participation in horrors, positive significance, some parameter of positive meaning for horrors other than 'educational' benefit must be found!" (Adams 1999a, p. 53).

Later on I show how mystical body theodicy offers another benefit that constitutes a way of being good to sufferers of dysteleological (and other) evils during the suffering phase of their life.

\subsection{Adams, Redemptive Suffering, and Social Evil}

According to Adams other theodicies such as Swinburne's and Hick's do not resolve the problem of evil because they do not adequately account for horrendous evils. A horrendous evil is an evil "the participation in which (that is, the doing or suffering of which) constitutes prima facie reason to doubt whether the participant's life could (given their inclusion in it) be a great good to him/her on the whole" (Adams 1999a, p. 26). Elsewhere she says horrendous evils have "power prima facie to degrade the individual by devouring the possibility of personal meaning in one swift gulp" (Adams 1999a, p. 29). A good God would be good to participants in horrendous evils. To be good to them he would need to restore personal meaning and give them reason to think their life is a great good to them. To do this, horrendous evils need to be defeated in the context of a person's life; that is, they must be given "positive meaning through organic unity with a great enough good within the context of his/her life" (Adams 1999a, p. 31).

Horrendous evils can be defeated by being a vehicle of unity with God—the greatest possible good, incommensurate with any other goods-or a means through which God honors us. Being honored by the greatest possible good and being unified with that being are both great goods sufficient to defeat evil. Adams offers various models to show how such defeat is possible. First, God honors us by suffering with us and having compassion on us. Our suffering thus acquires symbolic value as a dimension of God-likeness. In addition, through suffering we resemble God in bringing about human redemption by absorbing rather than striking out against evil. Second, suffering is a vision into the internal life of God, enabling us to see the depths of his love for us. Third, God will welcome us into heaven and thank us for the sufferings we went through while participating in his creation project. He will also "publicly compensate us for what we have undergone" and these rewards will "bring everlasting honor and unending joy" (Adams 1999a, p. 163). Fourth, God not only redeems but honors humanity by becoming incarnate and himself suffering horrendous evils. Those who participate in horrendous evils can thus identify with God, giving them a unique relationship with God and appreciation of the depths of his love and mercy. ${ }^{5}$ Again, a core assumption of all of these

5 She offers a fifth model inspired by Jurgen Moltmann. I leave it out for the sake of space. 
models is that being honored by and being unified with a perfect and incommensurately good God is itself incommensurately good, and thus can defeat horrendous evils as long as the participant in such evils acknowledges and internalizes that honor and unification.

Philip Quinn argues that Adams' theodicy fails to account for social evils. She can explain how God might redeem horrendous evils individuals participate in, but what about evils that societies participate in, e.g., "the system in this country that permits the homeless to spend winter nights huddled on the subway grates of Manhatten while others live in decadent luxury" (Quinn 1993, p. 192)? Quinn takes it that social evils are sometimes horrendous and are not reducible to a set of individual evils. All of the four models above involve individual—not social—participants in horrendous evils being honored or unified with God. Those models are thus inapplicable to social evils.

John Cobb (Cobb 1997) offers a quite different criticism, aimed at the fourth model. Adams is a universalist about salvation: everyone eventually will experience God in a beatific vision in the afterlife. But if everybody ends up getting the beatific vision-in which God unifies with us and honors us-how can it be an adequate compensation for those who have participated in horrendous evils? It seems like those participants should get something better, but they don't because all experiences of God are incommensurate. Adams does say that those participants will have a distinct kind of experience of God exactly because of their having experienced horrendous evils (as Jesus did); their relationship with God will have a special sort of intimacy. But does that specialness suffice for making adequate compensation when the alternative is to not participate in horrendous evils, maybe participate in some lesser evils, and experience a different, somewhat analogous, intimacy with God? It's not so clear.

Later on I show how mystical body theodicy can both explain how social evils are redeemed and also incorporate participation in horrendous evils more tightly into a relationship with God; tight enough to plausibly overcome Cobb's objection.

\section{The Doctrine of the Mystical Body of Christ}

The doctrine of the mystical body of Christ is built on the idea that humanity was intended by God to be, in some respects remains, and yet in other respects has fallen from being a unity. Redemption consists in part in reincorporation into the proper unity intended for humanity. As Henri De Lubac writes, "the redemption being a work of restoration will appear to us by that very fact as the recovery of lost unity-the recovery of supernatural unity of man with God, but equally of the unity of men among themselves" (De Lubac 1988, p. 35). This unity is more than a likeness in faith, will, and value; it is a social unity that is spoken of as being like the unity of a body.

This theme of humanity's intended unity shows up right at the beginning of the Bible in the story of creation and fall. In the second creation story in Genesis 2 Adam-whose name means 'humanity' - is the entirety of humanity. But "it is not good for the man to be alone" (Gen 2:18), and so God creates Eve from Adam. ${ }^{6}$ A little society is created from one being. And the two are meant to continue to live in some sort of unified existence-“"a man will leave his father and mother and be united to his wife, and they will become one flesh" (2:24). Part of the problem with sin is that it sunders the unity amongst humanity; after eating the forbidden fruit they realize their nakedness and put on clothes, thus hiding themselves from each other. Adam tries to shift responsibility onto Eve for their sin, breaking unity of purpose. Soon sin divides their family. Cain's jealousy of Abel leads him to kill Abel; as punishment God sends Cain away and he becomes "a restless wanderer on the earth" (4:14). The theme is clear: humanity begins as a single entity, is to remain a unity even as it divides and multiplies, but sin damages humanity by tearing apart its unity and thus preventing humanity from

6 All Bible quotations are taken from the NIV translation. 
being what it was meant to be. Augustine highlights this theme with a memorable metaphor: "Set in one place, [Adam] fell and, as it were, broken small, he has filled the whole world." ${ }^{7}$

God's restoration project through Abraham aims to restore this lost unity. Abraham isn't chosen to be a lone guru who follows God, perhaps inspiring others to do so also. He is called to be the father of a nation of people, Israel, who are collectively God's chosen people. The nation is called to be holy (Lev. 11:44-45; 20:7), thus manifesting the image of a holy God. And God tells Abraham at his calling that "I will make you into a great nation," and that "all peoples on earth will be blessed through you" (Gen 12:2-3). Abraham is thus thought of as the father of a nation and through that nation the world will be blessed. How? By being a witness to the holy God, but also by representing what that God wants for humanity: a collective unity that is holy like God. Isaiah makes it clear that all are welcome to bind themselves to the Lord, follow the law, "hold fast to my covenant" (Isa. 57:4) and receive God's blessing. "My house will be called a house of prayer for all nations" (Isa. 57:7).

From a Christian perspective, God's restoration project needs another layer of divine assistance- - the incarnation of the Son of God, Jesus. Jesus doesn't come just to save a set of individuals; he comes to save humanity by saving the nation of Israel. According to the gospel of Luke, when Jesus is brought to the temple for circumcision, Simeon, who "was waiting for the consolation of Israel" was promised by God to see the Christ. When he does, he proclaims "my eyes have seen your salvation ... a light for revelation to the Gentiles and for glory to your people Israel" (Lk. 2:25, 30, 32). Anna, a prophetess, after seeing Jesus "spoke about the child to all who were looking forward to the redemption of Jerusalem" (Lk. 2:38). The gospel of John expresses this theme very clearly. The gospel writer says that the high priest Caiaphas "prophesied that Jesus would die for the Jewish nation, and not only for that nation but also for the scattered children of God, to bring them together and make them one" (Jn. 11:51-2). Later in the gospel Jesus prays for the unity of his disciples: "Holy Father, protect them by the power of your name-the name you gave me-so that they may be one as we are one" (Jn. 17:11). ${ }^{8}$ Since Christians believe that Jesus and the Father are two persons in one God (two of the three Trinitarian members), this is indeed a strong statement of unity.

The book of Acts and the various New Testament epistles describe how the early Christians went about becoming one and how they thought of their unity. Acts describes the followers of Jesus as being "one in heart and mind,... [sharing] everything they had" (Acts 4:32). Paul makes a complicated argument in Romans 9-11 that God's promise to Israel has not been violated because he has saved Israel through a remnant-namely, the followers of Jesus, the Church, to whom gentiles have been grafted. In Ephesians he argues that the gentiles were once "separate from Christ, excluded from citizenship in Israel" (2:12), but that now Jesus has "made the two one ... his purpose was to create in himself one new man out of the two, thus making peace, and in this one body to reconcile both of them to God through the cross" (2:14-6). In First Corinthians 12 Paul famously depicts the followers of Jesus as being parts of one body: "Now you are the body of Christ, and each one of you is a part of it" (1Cor 12:27). Each member has a different role to play, contributing to the good of the body. Jesus "is the head of the body, the church" (Col. 1:18). The head, Jesus, supports, holds together, and grows the body (Col. 2:19). The word of Jesus, the head, dwells in the parts of his body (Col. 3:16). All of his people in his body "will in all things grow up into him who is the Head, that is, Christ" (Eph. 4:15). Christians thus ought to imitate Christ and God (Eph. 5:1-2). As a result of growing up into the Head, "from him [that is, Christ] the whole body, joined and held together by every supporting ligament, grows and builds itself up in love, as each part does its work" (Eph 4:16). This love that binds the parts of the body together is to be modeled on the love of Christ- "live a life of love, just as Christ loved us and gave himself up for us" (Eph 5:2). The author of 1John elaborates on the nature of this love: "This is how we know what love is: Jesus Christ laid down his life for us. And we ought to

From On Psalm 96, quoted in De Lubac (1988), p. 376.

This is the dominant theme of Jesus' prayer. See also Jn. 17:21, 22, 23, 26. 
lay down our lives for our brothers. If anyone has material possessions and sees his brother in need but has no pity on him, how can the love of God be in him?" (1Jn 3:16-17).

Paul finally brings us full circle, comparing the love of Christ for his body, the church, to the love of a husband for his wife who (and here he quotes Genesis 2) is united with him in one flesh (Eph. 5:28-32). The unity of the body of Christ-redeemed humanity-is thus modeled on the sort of unity humanity was intended to have by God at the very beginning. In contrast to his metaphor of Adam being broken and spread through the whole world, Augustine pictures the church as "One man ... that reaches to the end of the world." ${ }^{\prime \prime}$

The doctrine of the mystical body of Christ thus includes the following claims:

(MB1) Redemption involves restoring humanity to a proper unified state.

(MB2) The Church is the group of redeemed humans. ${ }^{10}$

(MB3) The redeemed humans in the Church form an organic body of sorts (the body of Christ), with Christ as the head of that body, guiding and growing it into the proper unified state.

(MB4) The members of the body of Christ ought to be unified with each other through love and acts of love.

Although different Christian sects may disagree about the details of how to understand the mystical body of Christ, these four claims are endorsed across the Christian tradition—by Roman Catholics, Protestants, and Eastern Orthodox. ${ }^{11}$

\section{Theodical implications}

The doctrine of the mystical body of Christ thus envisions humanity being intimately united by bonds of love, with the character of that love modeled on Jesus's love for humanity-a love that led him to be willing to lay down his life for humans. This unity will be a community of sorts. ${ }^{12}$ Forming such a community is a very great good, both from a Christian and a secular perspective. From a secular perspective, most agree with Aristotle that a human is by nature a political animal. We humans flourish best in communities, especially in communities in which we are loved. Loving relationships are great intrinsic goods, but they are also great extrinsic goods because of how love helps us to develop in our youth, conquer obstacles, survive threats to our life and well-being, achieve our goals, and connect emotionally with others. ${ }^{13}$ The Christian perspective incorporates and expands beyond these secular reasons. To love, and be loved, in a community of persons is a way of being like God who, on the Christian view, is a Trinitarian being, three persons bound by love. Resembling God-the perfectly good being-is itself a very great good (Adams 1999b, p. 28ff). Humans in such a community will not just resemble God, on the Christian view, but will also be united to God, through Jesus, who is himself a member-indeed the head—of the community. Being united with God, the greatest possible being, in a community of love is an immensely good thing.

Evil, both moral and natural, can increase (or provide opportunities for increasing) the bonds of unity among humanity. When Sally is injured in a natural disaster family, friends, and strangers may work individually or together to help Sally recover: binding her wounds, being with her in her suffering, bringing her food, offering her a place to stay, giving her work, helping resolve her insurance claims, etc. Through all of these acts, bonds of love are tightened and various people are wound more tightly together into a community of love. When Derek is unjustly beaten by another person

9 From Augustine, On Psalm 86.

10 For the purposes of this paper I will stay neutral about whether the Church—redeemed humanity-will ultimately include all humans (i.e., about whether salvific universalism is true).

11 See (Pius XII 1943; Berkhof 1941, pp. 447-53; Zizioulas 2006, pp. 286-307) respectively. (Mersch 2011), originally published in 1936, is still the best discussion of the history of the doctrine from scripture and the Church fathers through the scholastics.

12 It could be a community of communities. We can stay neutral about the structure this community will take.

13 For some concerns about whether a certain kind of neo-liberal secular viewpoint will regard this sort of unity of humanity as good, see (White 2016). 
family, friends, and strangers may work individually or together to help him: binding his wounds, being with him in his suffering, helping him to recover emotionally and physically, helping to bring him some justice from the law, and perhaps working to change laws or aspects of the culture that allow or encourage acts like what Derek suffered. Once again, through all of these acts, bonds of love are tightened and various people are wound more tightly into a community of love.

These are just two hypothetical (but realistic) examples; many more are readily constructed. One point they illustrate is that both moral evils (in Derek's case) and natural evils (in Sally's case) can increase the unity of humanity. The mystical body theodicy can thus explain evils of both sorts (many theodicies only apply to one or the other). They also illustrate that bonds of love can be tightened in a variety of ways. Individuals can come to love each other better, but also societies can change in ways that both enable societies to love their members and enable members of the society to love each other better. Take Derek's case for instance. If laws and policing practices were to change to prevent abuse of the sort he suffered, then society as a whole would treat its people better; society as a whole could then be said to love certain members better than in the past. And those laws and practices would enable individual lawyers and police to perform more loving acts to the members of the community.

I haven't said whether Sally or Derek have been incorporated into the body of Christ. But whether they are or aren't, evils suffered have in their cases led to goods of unity. If they aren't incorporated into the body of Christ, they still have become more unified in bonds of love to other people and to a human society. As mentioned above, there are secular reasons to think that these are very good things. And MB1 implies that these are very good things as well. If Sally and Derek are incorporated into the body of Christ, in addition to all of these goods they may also become more tightly bound to Christ if, e.g., they begin to pray to him and rely on him more, or the Church manifests the love of Christ by loving them, or they see the good deeds and love of others as God's means of working in the world. Even if Sally and Derek aren't Christians, the love that other people show them could well be God's means of drawing them to him as a manifestation of divine love.

On the Christian view there are two additional goods to be gained in situations in which an evil suffered brings about the goods of human unity. First, one who suffers such an evil imitates Christ. Paul expresses a deep desire to know "the fellowship of sharing in his sufferings, becoming like him in his death" (Php. 3:10). When one suffers and one's suffering increases the unity of humanity, one resembles Christ by suffering for the redemption of humanity (see again MB1). To be sure Christ's suffering for the redemption of humanity is unique: only he offers a sacrifice for the sins of humanity. But he offers that sacrifice to bring about an end result-the reconciliation of God and humanity, the latter united into a body with Christ as the head. When one's suffering increases the unity of humanity, one's suffering also (to some degree) brings about an aspect of the same end result. Imitating Christ by suffering for the redemption of humanity is in some ways a great good. Imitating a perfect being and playing a role in his redemptive goals are great goods. Being willing to play this role brings about the second additional good: becoming more tightly unified with Christ, and thus directly contributing in one's own person to the unification of humanity.

Marilyn Adams has persuasively argued that a good God wouldn't simply balance out the amount of good and evil in the universe. She writes, "Divine love would not subject some individual created persons to horrors simply for the benefit of others or to enhance cosmic excellence" (Adams 2006, p. 45). He would also be good to each person in his creation. Sally and Derek in my examples above both get to enjoy the tighter bonds of love that result from the suffering they undergo; arguably God can be said to be good to them despite allowing these sufferings. But there will be many people who do not enjoy the tighter bonds of love that result from their sufferings: some will die in the midst of their suffering, others will be too damaged physically or emotionally to participate in those bonds of love. Like Adams, I say that God can be good to these sorts of people by giving them an opportunity to subjectively appropriate the threefold goods (described above) of (a) increased unity of humanity, (b) imitation of Christ by contributing to the redemption of humanity, and (c) increased unity with Christ. To subjectively appropriate these goods one must recognize that they are good and endorse 
or enjoy one's role in producing or participating in them. The wretched depths of suffering and its effects in this life imply that God will need to provide some people an opportunity to appropriate the threefold goods in an afterlife. ${ }^{14}$

Mystical body theodicy is closely related to, but distinct from soul making theodicy. Their distinction lies in their account of how evils contribute to good. According to soul making theodicy, evils contribute to the good of individuals becoming more virtuous. According to mystical body theodicy, evils contribute to the unity of humanity in love (and to imitation of and unity with Christ). For soul making theodicy, the good is an individual good. For mystical body theodicy, the good is a social good. Of course, social goods tend to result from and require individual goods. When humanity becomes more united, almost assuredly some people are becoming more virtuous. But the unity of humanity is distinct from those people becoming more virtuous. For people can become more virtuous without humanity becoming unified; we can become more virtuous in the desert with little human interaction. Perhaps some human interaction is required since, as Aristotle argues, a person's virtue cannot be a mere disposition—it must be exercised. Even so, far less exercise is required for the possession of virtue than is required for love of another or for the unity of humanity.

Evan Fales has an objection to Eleonore Stump's theodicy which might also apply to mystical body theodicy. ${ }^{15}$ He claims that it is unjust for a person A to put someone, B, through suffering $S$ even if $A$ knows that $B$ will benefit from and even be happy to have gone through $S$ because of some good G that results (Fales 2013, pp. 353-54). So it is unjust for God to put a person through suffering even if that suffering results in the threefold goods and that person subjectively appropriates those goods. I reject this argument for two reasons. First, according to mystical body theodicy God doesn't put humans through suffering; he allows such suffering in part because he can redeem it with the threefold goods, so there's an important doing/allowing distinction here. Second, following Swinburne, I think because God is humanity's creator and benefactor God has a right to allow humans to endure suffering as long as (i) that suffering produces goods for some part of the family of his creation and (ii) God can be good to the sufferer in his suffering (Swinburne 1998, pp. 223-36). Fales himself seems to grant that this objection carries little force, for he quickly develops the objection in a slightly different direction: what is unjust is the distribution of suffering. Plausibly suffering isn't distributed in a way that best fulfills "the greatest good for each of those individuals [i.e., those who suffer]" (Fales 2013, p. 356). Maybe this objection applies to Stump, but it doesn't apply to me. Mystical body theodicy does not assume that evils suffered that produce the threefold goods fulfill the greatest good for the sufferers. Rather, it assumes only that the threefold goods are great goods and that, when subjectively appropriated, one's life is a great good for oneself, and thus that God can be good to one through one's sufferings (that is, the sufferings that produce the threefold goods).

We are now in a position to show how mystical body theodicy can help Hick, Swinburne, and Adams avoid objections to their theodicies. Each discussion will also deepen our understanding of mystical body theodicy.

Hick's soul-making theodicy seemed unable to fully explain dysteleological evils-evils that appear to not contribute to soul-making. Hick argues that these evils can contribute indirectly to soul-making if people find such evils mysterious and are thus motivated to have compassion toward those who suffer them. Adams argues that God needs to be good to those who suffer dysteleological evils during the phase of their life in which they suffer and he doesn't do that just by giving them an opportunity in the afterlife to become more virtuous and Godlike by embracing how their suffering has led to the soul making of others.

Mystical body theodicy can say that God is good to them during the time of their suffering: he is allowing them to play a role, through their suffering, in the redemption of humanity by encouraging

14 See (Adams 2006, pp. 205-41) for further defense of this point.

15 Stump's theodicy is presented most fully in (Stump 2010). 
humanity to become more unified. The sufferer may only come to subjectively appropriate and so value this role in the afterlife, but nevertheless from the afterlife the sufferer can look back and accept that God was good to him/her at that time of his/her life by giving him/her this role to play. To take this perspective the sufferer must come to personally value ${ }^{16}$ several things: God, unification with God, imitation of God, and the unity of humanity. God surely has the resources to guide people to this perspective.

Swinburne's theodicy proposes that suffering moral evil carries with it the good of being of use to the perpetrator's exercise of free will. The problem with this proposal is that the good of being of use for A depends upon the value of A and it doesn't seem that freely performing a wrong action is all that valuable.

Mystical body theodicy suggests that there is another, much more valuable, end that we can be of use for when we suffer: the good of helping to increase the unity of humanity. For the reasons mentioned earlier, the unity of humanity is a very great good; surely much greater than the good of exercising free will wrongly. There may be some good in the latter; mystical body theodicy doesn't aim to replace Swinburne's proposed good with another, but rather to enliven the idea that it can be good to be of use by suggesting an additional good that is often served when a person suffers. It is also worth emphasizing that according to mystical body theodicy one is not merely of use, when one suffers, for increasing the unity of humanity. Remember the threefold goods. The sufferer himself also imitates Christ and has an opportunity to develop a greater unity with Christ.

Lastly we turn to Adams's theodicy. Mystical body theodicy draws on some of the same ideas that Adams uses in her theodicy, most notably that unity with Christ is a great value and that suffering can be a vehicle to greater unity with him. I've also incorporated her claim that in his goodness God would be good to people who have suffered evils. The other aspects of her theodicy mentioned earlier are consistent with (even if they are not directly incorporated into) mystical body theodicy.

Mystical body theology can help Adams respond to the two worries facing her theodicy: Quinn's concern that social evils are not redeemed and Cobb's worry that a special sort of intimacy with God, through suffering, isn't sufficient compensation given Adams's universalist assumption. Mystical body theodicy is well-equipped to explain how social evils can be redeemed-the redemption of humanity consists (in part) in humanity forming a unified body, with Christ as head, that is bound together by love. This body, the Church, is a society. That society, fully redeemed, will not be possessed by social evil. All social arrangements will be motivated by, and will embody, the love of Christ. The suffering, even horrendous suffering, of individuals due to social evil provides an opportunity for that social evil to be overcome, or at least combatted, by groups of people coming together in love to change their society. Human societies this side of paradise will no doubt continue to be tainted with social evil, and many-perhaps all-human societies will pass away in paradise and be replaced by something more divine. ${ }^{17}$ Probably the USA, the UK, the Boy Scouts, and the NFL (just to take a few randomly-chosen examples) won't continue on in the fullness of redeemed humanity. But it is nevertheless good for humanity to become more unified in temporary societies like these. For surely the unity of love is good wherever it is found, and traces of it will endure through societal transformation and replacement.

In her later work, Adams briefly discusses the doctrine of the mystical body (not under that description, just as the idea that the Church is the body of Christ with Jesus as head) in the context of her theodicy. She says that humans are social animals and that part of what makes us human is that we have capacities for certain kinds of social interaction (Adams 2006, pp. 195-96). However, social systems produce horrors (p. 195). Divine indwelling, once one is opened up to it, bears social fruits by coordinating and harmonizing the transformation of each person, moving them into a "wholesome

16 Rather than merely acknowledge the value of these things.

17 As Adams herself notes in a very brief reply to Quinn (Adams 1993, p. 186). 
community" (p. 163). These people thus grow to become "functional organs of Christ's body in the world" (p. 163). The primary functions of this Church, to be carried out by Christ's organs, are testimony and solidarity: testifying to the horrors we experience, and proclaiming God's love for us and his desire to defeat those horrors. Christians testify with words and with the example of their own lives in which horrors are being defeated by solidarity with Christ. Christians also stand in solidarity with humans-helping those who have suffered horrors (p. 202). The Church's efforts will not be completely successful in this age. The Church itself remains vulnerable to horrors, and indeed perpetrates horrors (p. 203). So we must trust primarily in the head of the Church, Christ, to eventually defeat all horrors. In the meantime we can participate critically in the efforts of the Church.

What she says here is good as far as it goes, but it doesn't go far enough. It is one thing to say that part of what makes us human is that we are capable of certain kinds of social interaction, and quite another to say we flourish best in, and so redeemed humanity will live in, a body-like community. The latter claim, central to the doctrine of the mystical body and so to mystical body theodicy, is what explains why the unity of humanity in love is a highly intrinsically valuable end, thus enabling us to explain how social evils can be defeated. They can be defeated, according to mystical body theodicy, in two ways. First, like Adams's view, social evils ${ }^{18}$ can be defeated in the lives of individual persons; that is, the evils individuals have suffered because of social structures can be defeated in those individuals' lives. I've described above how such defeat comes about: by subjectively appropriating the threefold goods connected with suffering evil when that evil leads to (or provides an opportunity to lead to) an increase in the unity of humanity. Second, social evils are also defeated in humanity. Humanity is redeemed into a community (the Church), manifesting divine love, powered by the Holy Spirit, headed by Christ the redeemer. Humanity, through suffering social evils, participates in its own redemption when those social evils bring about greater unity.

An analogy might be helpful. If we, as a team, played poorly in a basketball game the best sort of redemption would be one in which the team is able to overcome the poor performance, responding to and defeating its previous weaknesses, in a new team performance. As humans we by nature seek to work together to accomplish various goods. And we fail together (each person participating in different ways). The best sort of redemption for humans would thus be in a community where we are able to succeed in pursuing these various goods together, responding to and defeating our previous weaknesses. The Church is the place where this happens.

Lastly, we turn to Cobb's objection to Adams's theodicy: intimacy with God, through suffering a horrendous evil, is an insufficient compensation for that evil given that, on her view, all will eventually be saved and experience intimacy with God. If I'm going to get intimacy with God eventually, why should I value going through a horrendous evil? Sure, it gives me a unique kind of intimacy with God, but is that worth it? Mystical body theodicy says that, in suffering evils, you may get more than a unique variety of something you were going to get anyway (i.e., intimacy with God)-you get to be a part of God's redemption of humanity and your suffering contributes to that redemption by increasing the unity of humanity. As argued above, the unity of humanity is a great good, and so contributing to that unity is also a great good. Notice the crucial point: salvific universalism doesn't imply that all will get to play such a role. Some will and some will not. Those who do experience a distinct and great good.

\section{Limitations}

Mystical body theodicy draws attention to a great good-the unity of humanity-that can plausibly contribute to explaining why God might allow evil. Mystical body theodicy is best combined with other prominent theodicies, yielding an explanation for a broader range of evils and, as argued in section four, patching some holes in other theodicies. But I don't think that mystical body theodicy,

18 Horrors, more specifically, on her view. But I'll continue to speak more generally of social evils being defeated. 
even combined with other theodicies, gives us a global theodicy. I doubt we'll ever have a plausible global theodicy. But we don't need a plausible global theodicy in order for theodicy to undermine the problem of evil. In this section I discuss some of the limitations of mystical body theodicy and some broader implications for whether theodicy undermines the problem of evil.

Mystical body theodicy helps explain why God might allow evils that in some way contribute to the unity of humanity. But many evils don't so contribute. The most obvious examples of such evils are the suffering of many animals, especially organisms that existed before humans evolved. Some contemporary animal suffering has contributed to the unity of humanity-the suffering of pets, livestock, and endangered species. Humans have worked to protect these animals and their efforts have drawn them together into a tighter unity of purpose, working towards good. But humans don't rally around all animal suffering; indeed probably a lot of animal suffering is simply unacknowledged by humans.

It is possible that one day humans will grasp the full range of animal suffering and as a result come together to better care for animals. If that were to happen, then mystical body theodicy might contribute to explaining why God allows animal suffering. But even so I don't think we'd have a plausible complete theodicy of animal suffering. Plausibly, God should be good to animals and if much of their suffering could only be justified by its contribution to the unity of humanity, then God wouldn't be good to all the animals that have suffered. He would be good to us through their suffering, but not good to them. In addition, surely the resulting good of the way humanity becomes unified in response to animal suffering could have been achieved with considerably less animal suffering. A lot less suffering could have happened before we evolved, for example, and plausibly our subsequent movement toward unity wouldn't have been affected one bit. So a lot of animal suffering would still appear gratuitous even if humans were to become aware of the extent of animal suffering and move toward greater unity as a result.

A similar line of argument goes for some human suffering. Some human suffering doesn't increase the unity of humanity. Some people die of diseases or natural disasters and nobody much cares about their loss. God might one day give us knowledge of all such cases and this knowledge might move us to greater unity, but again it isn't clear that we'd be moved any less by a lesser amount of such evil.

This is a familiar argument in discussions of the problem of evil, and indeed it is often leveled as a general objection to theodicies: even considering all of the possible goods connected with evil that are put forward by the best theodicies, it still seems that God could have gotten those goods with somewhat less evil. So there is gratuitous evil. God wouldn't allow gratuitous evil, so God doesn't exist. And if that argument is correct, then one might question mystical body theodicy as follows: "this is an interesting theodicy which points to an important good. But it doesn't help! There's still plenty of gratuitous evil, for the reason given in the argument I just gave."

I have two replies to this line of questioning. First, a theodicy can be valuable even if it doesn't completely explain why God might allow evil (or completely explain all of the remaining apparently unexplained cases). A theodicy is valuable if it explains more (or better explains) evils, or explains some of the previously apparently unexplained cases. Mystical body theodicy, for the reasons discussed in the previous section, does this. Second, even if the combined force of our best theodicies can't explain all evil, we shouldn't automatically conclude that there is gratuitous evil. For we can think of the existence of God plus the theodicies as a theory. Theories commonly face anomalies-phenomena that seem difficult to square with the theory-but the mere existence of anomalies doesn't justify rejecting the theory. There will inevitably be some anomalies given human error in data collection and analysis; such error is certainly present when thinking about why an event might justifiably occur since discerning whether it is justifiable depends upon discerning its effect on the world in the near term and far term. Our grasp of this information is limited and subject to mistake in assessment. So, to conclude that there are gratuitous evils and thus that God does not exist we would need to think carefully about 
whether the apparently gratuitous evils are merely anomalies; making such a determination is quite challenging. ${ }^{19}$

\section{Conclusions}

Mystical body theodicy proposes that God might allow some evils in part because those evils contribute to increasing the unity of humanity, a unity woven by the bonds of love. This unity is a great good from a secular perspective, since we are social creatures and flourish by working together and by living in loving relationships. It is also a great good from a Christian perspective, which says that salvation consists in part in humanity becoming unified in a body with Christ as the head. Those who suffer evils that contribute to the unity of humanity may be compensated with a threefold good: the good of helping to increase something of great good (the unity of humanity), the good of imitating Christ (who also suffered to bring about the unity of humanity in salvation), and if one subjectively appropriates the previous two goods, one obtains the good of becoming oneself more tightly bound into redeemed humanity, the Church. God is good to those who have subjectively appropriated these goods. Mystical body theodicy also immunizes three other prominent theodicies from various objections, thus filling gaps in their theodicies. I grant that there are limitations to mystical body theodicy, even if it is combined with other prominent theodicies. For some evils, it is difficult to explain why God would allow them. But mystical body theodicy does offer an additional explanation for many evils, and an explanation for some evils that otherwise might be difficult to explain. So mystical body theodicy positively contributes to theodical responses to the problem of evil. Whether the problem of evil is completely rebutted is difficult to judge; I've outlined some grounds for reservation about whether the remaining unexplained evils give good evidence against God's existence.

I want to conclude by pointing to one final advantage of mystical body theodicy. Most responses to the problem of evil are defenses-that is (according to my terminology) they argue that there isn't good reason to believe some premise of the problem of evil. This makes sense strategically-why do more than is necessary to ward off an objection? But it's one thing to merely ward off an objection to a claim $\mathrm{T}$, and another to ward it off in a way that makes $\mathrm{T}$ more attractive. The latter, if you can do it, is more rationally valuable than the former. Strong theodicies-theodicies that attack a premise of the problem of evil, arguing that it is probably false-can make theism more attractive if it can be shown that a good God would probably allow evils for a reason $\mathrm{R}$ where $\mathrm{R}$ is clearly a great good even from a secular perspective. Theism can then be seen to be more coherent (rather than not seen to be incoherent) and committed to something of great value. Adams's rejection of the myth of shared values can obscure the fact that there are some shared values, and that there is an epistemic benefit to be gained for theism from capitalizing on those values to attack premises in versions of the problem of evil.

Arguably, from both a secular and Christian perspective, God probably would allow certain evils if they were redeemed by the threefold goods. The good of a unified humanity really does seem to be very great and we are already quite familiar with—indeed we honor-people who willingly sacrifice their interests or even their lives for the sake of a great good. Assuming I have shown that mystical body theodicy is in this way a strong theodicy, Christian theism will then be seen to be more coherent to nontheists who have read and bought my argument. Christian theism will also be seen to be committed to working toward the good of the unity of humanity in love; indeed the purpose of the Church is in part to increase this unity by redeeming many evils. ${ }^{20}$ The mission of the Church will thus also be seen to be a great good from a secular perspective, making Christian theism more coherent, rationally attractive, and even morally attractive. ${ }^{21}$

19 See (Dougherty and Pruss 2014) for a more careful and thorough discussion of anomalies and the problem of evil.

20 To avoid Pelagianism we should add the following qualification: by and through the grace of Christ, the Head.

21 I dedicate this essay to the memory of Marilyn McCord Adams, whose work and character has inspired me and inspired much of the thought in this essay. 
Conflicts of Interest: The author declares no conflict of interest.

\section{References}

Adams, Marilyn McCord. 1993. God and Evil: Polarities of a Problem. Philosophical Studies 69: 167-86. [CrossRef] Adams, Marilyn McCord. 1999a. Horrendous Evils and the Goodness of God. Ithaca: Cornell University Press. Adams, Robert Merrihew. 1999b. Finite and Infinite Goods. New York: Oxford University Press. Adams, Marilyn McCord. 2006. Christ and Horrors. Cambridge: Cambridge University Press. Berkhof, Louis. 1941. Systematic Theology. Grand Rapids: Eerdmans.

Bergmann, Michael. 2009. Skeptical Theism and the Problem of Evil. In Oxford Handbook of Philosophical Theology. Edited by Thomas P. Flint and Michael Rea. Oxford: Oxford University Press, pp. 374-402.

Cobb, John. 1997. Theodicy and Divine Omnipotence. In Philosophy and Theological Discourse. Edited by Stephen T. Davis. New York: St Martin's Press, pp. 199-203.

De Lubac, Henri. 1988. Catholicism: Christ and the Common Destiny of Man. San Francisco: Ignatius Press.

Trent Dougherty, and Justin P. McBrayer, eds. 2014. Skeptical Theism: New Essays. Oxford: Oxford University Press. Dougherty, Trent, and Alexander Pruss. 2014. Evil and the Problem of Anomaly. Oxford Studies in Philosophy of Religion 5: 49-87.

Fales, Evan. 2013. Theodicy in a Vale of Tears. In The Blackwell Companion to the Problem of Evil. Edited by Justin McBrayer and Daniel Howard-Snyder. Malden: Wiley Blackwell, pp. 349-62.

Daniel Howard-Snyder, ed. 1996. The Evidential Argument from Evil. Bloomington: Indiana University Press.

Hick, John. 1966. Evil and the God of Love. London: Macmillan.

Justin P. McBrayer, and Daniel Howard-Snyder, eds. 2013. The Blackwell Companion to the Problem of Evil. Malden: Wiley Blackwell.

Mersch, Emile. 2011. The Whole Christ: The Historical Development of the Doctrine of the Mystical Body in Scripture and Tradition. Translated by John R. Kelly. Eugene: Wipf \& Stock.

Pius XII, Pope. 1943. Mystici Corporis Christi: On the Mystical Body of Christ. Available online: http:/ /w2.vatican. va/content/pius-xii/en/encyclicals/documents/hf_p-xii_enc_29061943_mystici-corporis-christi.html (accessed on 10 September 2017).

Quinn, Philip L. 1993. Social Evil: A Response to Adams. Philosophical Studies 69: 187-94. [CrossRef] Swinburne, Richard. 1998. Providence and the Problem of Evil. Oxford: Oxford University Press. Stump, Eleonore. 2010. Wandering in Darkness. Oxford: Clarendon Press.

White, Thomas Joseph. 2016. An Age of Discontent. First Things, November, 25-31.

Zizioulas, John. 2006. Communion and Otherness. London: T\&T Clark.

(C) 2018 by the author. Licensee MDPI, Basel, Switzerland. This article is an open access article distributed under the terms and conditions of the Creative Commons Attribution (CC BY) license (http://creativecommons.org/licenses/by/4.0/). 